\title{
Problematika práva udělení amnestií ve světle amnestií udělených Vladimírem Mečiarem na Slovensku
}

\author{
Dominik Hoda \\ Západočeská univerzita v PIzni, Fakulta právnická
}

Anotace: Tento článek pojednává o amnestiích udělených předsedou vlády Slovenské republiky Vladimírem Mečiarem v roce 1998 v souvislosti s únosem Michala Kováče ml. a zmařeném referendu. Popisuje skutkové podstaty těchto událostí, přibližuje náladu na Slovensku a vleklé pokusy o jejich zrušení. Nakonec vše srovnává se situací v České republice, zabývá se právní úpravou udělení amnestií a přechodu této pravomoci na předsedu vlády a poukazuje na nebezpečí podobné situace jako na Slovensku na konci 20. stol.

Klíčová slova: amnestie, milost, Mečiarovy amnestie, sebeamnestie

Abstract: This article discusses the amnesties awarded by Prime Minister of the Slovak Republic Vladimir Meciar in 1998 in connection with the kidnapping of Michal Kovac $\mathrm{ml}$. and a frustrated referendum. It describes the facts of these events, describes the mood in Slovakia and protracted 
attempts to cancel them. Finally, it compares the situation in the Czech Republic, deals with the legal regulation of the granting of amnesties and the transfer of this power to the Prime Minister and points out the danger of a similar situation as in Slovakia in the late 20th century.

Keywords: amnesty, grace, amnesty of Mečiar, self-amnesty

\section{Úvod}

Právo hlavy státu udělovat amnestii je tradiční institut, jejž známe z dob monarchie, kdy nejvyššími soudci byli králové a císaři, kteří rozhodovali o osudu a trestu ostatních lidí. Tato "tradice“ zůstala dodnes v jistém slova smyslu zachována a transformovala se do moderního a demokratického systému, důkazem toho budiž i ústavní systémy České republiky a Slovenské republiky. V Ústavě Slovenské republiky je v článku 102 písm. i) zakotvena pravomoc prezidenta udělovat amnestii, odpouštět a zmírňovat tresty uložené trestními soudy, nařizovat, aby se trestní řizení nezačínalo nebo aby se $v$ něm nepokračovalo, a zahlazovat tresty. Podle článku 105 odst. 1 náleži v případě nezvolení nového prezidenta, nesložení slibu nového prezidenta nebo ze závažných důvodů neschopnosti vykonávat funkci prezidenta vykonávat jeho pravomoci vládě, která může v takovém připadě pověřit svého předsedu výkonem pravomocí prezidenta republiky, kromě pravomocí v článku 102 písm. d) až g). ${ }^{1}$ Přechod pravomoci na předsedu vlády udělit amnestii je tedy dle Ústavy Slovenské republiky možné.

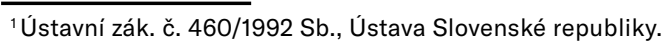


Tento příspěvek se zabývá závažným právním, politickým, ale i společenským problémem, který se dotkl Slovenské republiky na konci 20. století a jehož následky mají velký dopad na dnešní dobu, a to amnestií, kdy tehdejší předseda vlády Vladimír Mečiar v březnu roku 1998 nahradil na krátkou dobu ve funkci prezidenta Slovenské republiky Michala Kováče a ihned poté vyhlásil amnestii pro podezřelé ze spáchání trestného činu únosu Michala Kováče ml., ze které byl obviněn šéf Slovenské informační služby Ivan Lexa, a amnestii pro zmaření referenda o vstupu Slovenské republiky do NATO v roce 1997, nakonec srovnává právní úpravu s možností obdobné situace $v$ České republice.

\section{Pozadí udělení amnestií}

Od roku 1992 zkoumal na Slovensku Úřad organizované kriminality podvod ve slovenské společnosti Technopol, která zaplatila za dodávku textilie 2,3 milionu dolarů holandské společnosti Introcommerce, ovšem dodávka nebyla nikdy zrealizována. V Německu byl zatčen Petr Krylov za nedovolený obchod se zbraněmi, který, jak se posléze zjistilo ze svědeckých vypovědí, měl figurovat i ve zmíněném podvodu v Technopolu. Z výpovědi Krylova se zjistilo, že se na kauze Technopol spolupodílel i syn tehdejšího slovenského prezidenta Michal Kováč ml.

Na toho byl Mnichovským státním zastupitelstvím vydán zatykač a následně se stal hledaným INTERPOLEM. Prezident Michal Kováč vinu svého syna popíral. Na Slovensku narůstal tlak a zájem ze strany veřejnosti s názorem, že jde o politický 
problém. Ve vysokých politických kruzích rostla nevraživost mezi premiérem Vladimírem Mečiarem a prezidentem Kováčem, která vyvrcholila tím, že Michal Kováč udělil svému synovi amnestii v kauze Technopol. 31. srpna 1995 byl ve slovenské obci Svatá Jura Michal Kováč mladší unesen v autě, ve kterém ho únosci násilím opili, zbili a v bezvědomí převezli do rakouského Heinburgu před policejní stanici. Stopy vedly do nejvyšších pater SIS, kdy ředitelem v té době byl Ivan Lexa, blízký přitel Vladimíra Mečiara. O těchto skutečnostech vypovídal přislušník SIS Oskar Fegyveres, který později utekl ze Slovenska. Jeho přitelem byl policejní důstojník Robert Remiáš, který pár dní po výpovědi zemřel při výbuchu svého auta. Podezření padlo opět na SIS. ${ }^{2}$

Druhým připadem, který stál za kontroverzním udělením amnestií, bylo slovenské referendum v květnu roku 1997, které se týkalo prímé volby prezidenta, ovšem toto referendum prosazovala opozice, a protože koaliční vláda nechtěla být svědkem jejího úspěchu, zařadila do referenda další tři otázky ohledně vstupu Slovenské republiky do NATO, kdy na hlasovacích lístcích byly položené otázky záměrně formulovány tak, aby se na ně odpovídalo „NE“. Proti referendu se rozšiřila kampaň, která doporučovala referenda se nezúčastnit, a jelikož byla účast jen něco málo přes $9 \%$ místo $50 \%$ potřebných, bylo prohlášeno za neplatné a zmařené. Ze zmaření byl obviněn tehdejší ministr vnitra Gustáv Krajči. ${ }^{3}$

\footnotetext{
${ }^{2}$ JAMBOR, Eduard. Vplyv Slovenskej informačnej služby na charakter a transformáciu politického systému na Slovensku do roku 1998 [online]. [cit. 2019-09-04]. Brno, 2007. Dostupné z: https://is.muni.cz/th/bvign/. Bakalářská práce. Masarykova univerzita, Fakulta sociálních studií. Vedoucí práce Miroslav Mareš.

${ }^{3}$ LESNÁ, Luba. Únos prezidentovho syna alebo krátke dejiny tajnej služby [s.l.]. GMT a.s., 1998. ISBN 80-967947-0-1.
} 


\section{Udělení amnestií}

2. března 1998 skončilo funkční období prezidenta Michala Kováče, který i přes aféru svého syna v kauze Technopol setrval v Grasalkovičově paláci, a jelikož nebyla zvolena nová hlava státu, výkon pravomocí prezidenta přešel dle čl. 105 Ústavy Slovenské republiky na předsedu vlády Vladimíra Mečiara. Ten využil přechodu pravomocí prezidenta a druhý den, tj. dne 3. března 1998, podle článku 102 písm. i) vydal rozhodnutí předsedy vlády SK č. 55/1998 Sb., o amnestii, kde v článku V nařídil, aby nebylo zahajováno, a pokud se začalo, aby se zastavilo trestní stíhání za trestné činy spáchané $v$ souvislosti s prípravou a provedením referenda $z$ 23. května a 24. května 1997, a v článku VI, aby nebylo zahajováno, a pokud se začalo, aby se zastavilo trestní stihání za trestné činy spáchané $v$ souvislosti s oznámením o zavlečení Michala Kováče mladšího do ciziny. ${ }^{4}$ Po radách od právních expertů 7. července 1998 vydal dále rozhodnutí předsedy vlády SK č. 214/1998 Sb., o amnestii, kde byla formulace zastavilo trestní stíhání změněna na zastavilo trestní řizení pro podezření $z$ trestných činů, které měly být spáchány. ${ }^{5}$

Téměř ihned se po celé zemi zvedla vlna nevole a již 5. března se konalo $v$ Bratislavě několikatisícové shromáždění občanů Slovenska na protest proti zrušení referenda a vyhlášení amnestií. K protestu se přidala další řada osobností z řad politiků, právníků, ale i celebrit. Sám předseda vlády Mečiar uvedl, že „je to svrchovaná věc každého státu v jurisdikci

${ }^{4}$ Rozhodnutí předsedy vlády Slovenské republiky č. 55/1998 Sb., o amnestii [online]. [cit. 2017-07-09]. Bratislava: Ministerstvo spravedlnosti SR, 1998.

${ }^{5}$ Rozhodnutí předsedy vlády Slovenské republiky č. 55/1998 Sb. o amnestii [online]. [cit. 2017-07-09]. Bratislava: Ministerstvo spravedlnosti SR, 1998. 
rozhodovat sám, Evropská unie řekla svůj názor, my jsme řekli svůj názor a tím to skončilo“.6

Nicméně započala vleklá politická i právní snaha udělené amnestie zrušit. První pokus nastal už 8 . prosince 1998, kdy po skončení volebního období vystřídal na postu předsedy vlády Vladimíra Mečiara Mikuláš Dzurinda, který vydal rozhodnutí předsedy vlády o zrušení amnestií, Ústavní soud SR ve svém rozhodnutí o výkladu Ústavy SR z 28. června 1999, sp. zn. I. ÚS. 30/1999, tento pokus odmítl a podle A. Podivinské se z tohoto rozhodnutí dalo vyvodit, že "Mečiarovy amnestie je možné zrušit pouze změnou Ústavy $S R$, tedy formou ústavního zákona“"7

Ovšem navzdory amnestiím Policie SR pokračovala ve vyšetřování únosu Michala Kováče ml. a vraždy Roberta Remiáše. Národní rada v únoru 1999 zbavila imunity bývalého ministra vnitra Gustáva Krajčiho a v dubnu Ivana Lexu, který byl o několik dní později zatčen. 8. července 1999 se Ústavní soud vyjádřil, že premiér Mikuláš Dzurinda neměl právo amnestie zrušit. Na podzim v roce 1999 ředitel SIS zbavil Vladimíra Mečiara mlčenlivosti, aby mohl vypovídat o všech skutcích, ten však místo toho začal na protest držet hladovku.

${ }^{6}$ DANGL, Vojtech - BYSTRICKÝ, Valerián. Chronológia dejín Slovenska a Slovákov: Od najstarších čias po súčasnost. Dejiny $v$ dátumoch, dátumy $v$ dejinách, II. čast. Bratislava: Veda, 2014. ISBN 978-80-224-1373-2. Kapitola 1998, s. 1024.

${ }^{7}$ PODIVINSKÁ, Alexandra. Ústavný zákon o zrušení Mečiarových amnestií bol neúspešný [online]. [cit. 2016-12-01]. Legal \& Economic Press, s.r.o., 2016. 


\section{Pokusy o zrušení amnestií}

Od roku 1999 do roku 2017 bylo několik pokusů o zrušení Mečiarových amnestií. Ministr vnitra Ján Čarnogurský navrhl ústavní novelu, která by vylučovala amnestii proti únosům, ovšem Národní rada Slovenské republiky novelu neschválila. Aby byla novela přijata, bylo by třeba získat třipětinovou většinu hlasů poslanců v Národní radě. Tento pokus se nepovedl ani $v$ roce 2002. Téhož roku zastavil Krajský soud v Bratislavě stíhání Ivana Lexy. Dalšími neúspěšnými pokusy byly roky 2005 a 2008. V roce 2010 , při nástupu do funkce předsedkyně vlády, připravovala Iveta Radičová ústavní zákon, který by překonal účinky amnestií. Ovšem hlasovalo se až o návrhu poslanců na vydání ústavního zákona o zrušení některých rozhodnutí o amnestiích v únoru roku 2012, kdy pro zrušení hlasovalo jen 78 poslanců. Další hlasování proběhlo ještě v roce 2015 a 2016. Ovšem až v roce 2017, kdy se koaliční vláda za předsednictva Roberta Fica dohodla na zrušení amnestií, byl připraven další návrh. 30. března 2017 poslanci schválili návrh na změnu Ústavy při hlasování 124 poslanců pro. 4. dubna 2017 tedy nabyl účinnosti Ústavní zákon č. 71/2017 Sb., kterým se mění Ústava Slovenské republiky č. 460/1992 Sb. ve znění pozdějších předpisů. Byl to tedy celkově osmý návrh od roku 1999, který konečně prošel. Zrušeny byly amnestie Vladimíra Mečiara, ale i prezidenta Michala Kováče pro jeho syna Michala Kováče ml. Návrh obsahoval například čl. 88a, který byl později přijat do Ústavního zákona, a který říká, že „návrh na zrušení prezidenta podle čl. 102 odst. 1 písm. j) projedná Národní rada Slovenské republiky tehdy, když o to požádá nejméně pětina poslanců“. 8

${ }^{8}$ Ústavní zákon č. 71/2017 Sb., kterým se měni Ústava Slovenské republiky č. 460/1992 Sb., ve zněni pozdějších předpisů. 
Národní rada se také usnesla, že by schválení měl posoudit Ústavní soud Slovenské republiky, který na to má Ihůtu 60 dnů. Někteři soudci, například bývalá ústavní soudkyně Viera Mrázová, toto rozhodnutí kritizovali s tím, že soud je nezávislá instituce a neměl by být zatahován do politických bojů, nebo že je zbytečné rozšiřovat kompetence Ústavního soudu. ${ }^{9}$ Ústavní soud vydal 6 dnů před skončením Ihůty nález Ústavního soudu Slovenské republiky ze dne 31. května 2017, sp. zn. PL. ÚS 7/2017. V něm uvedl že „předseda vlády Vladimír Mečiar porušil princip zákazu svévole, princip legality, princip ochrany lidských práv a základních hodnot ve spojení s principem respektování mezinárodních závazků, princip dělby moci, princip transparentnosti a veřejné kontrolovatelnosti“.10 Zrušení zahrnovala i amnestii prezidenta Kováče udělenou jeho synovi, toho však německé soudy zprostily obvinění. Vyšetřován začal být také samotný Vladimír Mečiar. Soudní jednání s bývalým ředitelem SIS Ivanem Lexou stále nezapočalo, nebot dva soudci z lidu stále studuji spis, který má přes 20 tisíc stran, a soud s exministrem vnitra Gustávem Krajčim byl koncem roku 2018 dočasně přerušený.

\section{Právní úprava v České republice}

V českém právním řádu přisuzuje česká ústava, obdobně jako ta slovenská, v článku 63 odst. 1 písm. j) pravomoc hlavě státu nařizovat, aby se trestní stíhání nezahajovalo, a bylo-li zahájeno, aby se $v$ něm nepokračovalo, a dále právo udělat

${ }^{9}$ PRŮŠOVÁ, Veronika. Bývalá ústavní soudkyně: Kontrolní páku u Ústavního soudu nevidím [online]. [cit. 2017-03-22]. N Press, 2017.

${ }^{10}$ Nález Ústavního soudu Slovenské republiky ze dne 31. května 2017, sp. zn. PL. ÚS 7 / 2017-159. 
amnestii, podle článku 63 odst. 1 písm. k). Ústava České republiky v článku 66 také počítá s možností, že by se Česká republika ocitla bez personálního obsazení funkce prezidenta republiky, a to pokud ještě nový prezident nebyl zvolen, nesložil slib nebo nemůže-li prezident svůj úřad vykonávat ze závažných důvodů, kdy nastane tzv. mimořádná situace, kdy zde nový prezident být nemůže. ${ }^{11} \mathrm{~V}$ tomto případě, usnese-li se na tom Poslanecká sněmovna a Senát, přisluši výkon funkcí prezidenta republiky vyjmenovaných v čl. 63 Ústavy České republiky předsedovi vlády, vyjma vyhlašování voleb do Poslanecké sněmovny a Senátu a jmenování a povyšování generálů. Na předsedu vlády tedy přechází i právo udělovat amnestii a nařídit, aby se trestní rízení nezahajovalo, a bylo-li zahájeno, aby se v něm nepokračovalo. Amnestie se vyznačuje tím, že jde o hromadné promíjení a snižování trestů a právních následků odsouzení. Amnestie tedy není směřovaná $\mathrm{k}$ jednotlivci, ale ke skupinám jednotlivců nebo $\mathrm{k}$ určitým druhům trestných činů. Má povahu normativního aktu. ${ }^{12}$ Rozdíl mezi amnestií a milostí je v tom, že amnestie je obecná, milost je v užším slova smyslu individuální a spadá na konkrétního člověka. Milosti a amnestie mají různé formy a mezi základní patří agraciace, abolice a rehabilitace. Agraciací se promíji bud' celý pravomocně uložený trest, nebo jeho zbytek, abolice znamená nepokračování nebo nezahájení trestního řizení a rehabilitací se odstraňuji následky uloženého nebo vykonaného trestu a rehabilitovaná osoba je považována za bezúhonnou. Určitým zvykem je,

"ŠIMÍČEK, Vojtěch - FILIP, Jan - MOLEK, Pavel - BAHÝLOVÁ Lenka - PODHRÁZKÝ, Milan - SUCHÁNEK, Radovan - VYHNÁNEK, Ladislav. Ústava České republiky. Komentár. Praha: Linde Praha, 2010. 1536 s. ISBN 978-80-7201-814-7.

${ }^{12}$ PAVLÍČEK, V. a kolektiv. Ústavní právo a státověda, II. díl. Ústavní právo České republiky. 2., aktualizované vydání. Praha: Leges, 2015, 1152 s. 
že prezident uděluje amnestii $v$ posledních dnech svého funkčního období, zpravidla těm odsouzeným, kterým zbývá minimum času do vykonání trestu odnětí svobody za méně závažné trestné činy. Takové amnestie udělili Václav Havel i Václav Klaus. Velkou vlnu kontroverze v české společnosti zvedla v poslední době amnestie prezidenta Miloše Zemana udělená rozhodnutím prezidenta republiky o prominutí trestu podle čl. 62 písm. g) Ústavy České republiky Jiřímu Kajínkovi ze dne 23. 5. 2017, známému vězni pravomocně odsouzenému na doživotí.

\section{Problematika udělení tzv. sebeamnestie}

Velmi důležitá otázka je, jestli může v České republice nastat podobná situace jako na Slovensku ${ }^{13}$ a zda je tedy možné udělit tzv. sebeamnestii, tedy př́pad, kdy by na předsedu vlády České republiky přešla pravomoc prezidenta udělit amnestii a předseda vlády by ji udělil sám sobě. Český právní rád tento institut neupravuje, není tedy zakázáno udělit sebeamnestii, nicméně problematikou sebeamnestie se zabývá právní věda $v$ oblasti mezinárodního práva, například Úřad Vysokého komisaře OSN pro lidská práva ve své publikaci "Rule-of-law Tools for Post-conflict States - Amnesties“14 definoval sebeamnestii jako amnestii, která je „udělována těmi, kteří jsou zodpovědní za porušování lidských práv, za

\footnotetext{
${ }^{13}$ Předseda vlády Vladimír Mečiar neudělil amnestii sám sobě, ovšem je důvodné podezření, že $v$ těchto kauzách sehrál kličovou roli, a proto se zabývám podobným připadem, který by mohl nastat v České republice, nikoli stejným jako ve Slovenské republice.

${ }^{14}$ Rule-of-law Tools for Post-conflict States - Amnesties. New York and Geneva: United Nations, 2009, s. 43. Dostupné z: http://www.ohchr.org/Documents/Publications/ Amnesties_en.pdf
} 
účelem ochránit se před zodpovědností. Orgány ochrany lidských práv, právníci a jiné subjekty ostře kritizují sebeamnestie, protože svojí podstatou symbolizuji beztrestnost“. Další právníci, zejména američtí, na poli vědy mezinárodního práva ve svých publikacích uváděli, že sebeamnestie odporuje principu, že „nikdo nemůže mít prospěch ze svého zlomyslného konání“, a principu, že „nikdo nemůže být soudcem ve své věci“. Nutno podotknout, že udělování sebeamnestií se týkalo zejména porušování lidských práv a bylo využito v zemích, kde plně vládla diktatura nebo podobné režimy porušující lidská práva, nicméně zneužití sebeamnestie nemusí spočívat jen $v$ prípadě porušení lidských práv, ale i v demokratickém právním státu. Př́pady amnestie udělené sobě samotnému se zabýval i Meziamerický soud pro lidská práva v několika procesech, mezi nimi např. Barrios Altos v Peru 14. března 2001, Almonacid-Arellanoet al. v. Chile 26. záŕi 2006 nebo Gelman v. Uruguay 24. února 2011. Ovšem i na evropské půdě známe případ ve věci Marguš v. Chorvatsko, kterým se zabýval Evropský soud pro lidská práva. Dále například Komise OSN pro lidská práva ve své rezoluci 2004/72 z 21. dubna 2004 uvedla, že „amnestie by neměly být udělované těmi, kteři porušují lidská práva a páchají trestné činy“, a vyzývá členské státy, aby v souladu s jejich závazky z mezinárodních smluv provedly opatření k odvolání sebeamnestií a jejich nulifikování. Na výše uvedené případy odkazoval slovenský spolek VIA IURIS ve svém stanovisku Amicus curiae ke konání o přezkumu usnesení Národní rady SR o zrušení tzv. Mečiarových amnestií Ústavním soudem SR ze dne 16. 5. 2017.15

${ }^{15}$ VIA IURIS. Stanovisko Amicus curiae ke konání o přezkumu usnesení Národní rady $S R$ o zrušeni tzv. Mečiarových amnestii Ústavním soudem. Dostupné z: https://viaiuris. sk/wp-content/uploads/2017/09/VIA-IURIS-list-AMICUS-CURIAE-Meciarove-amnestie -16.5.2017.pdf 


\section{Závěr}

Jak již bylo řečeno, právní úprava zakazující sebeamnestii, jejiž zneužití může vést $k$ velmi nebezpečnému ohrožení státu a demokratického systému, chybí, ovšem dle mezinárodní právní vědy a organizací zabývajících se ochranou lidských práv je zcela nepřípustná, nelegitimní a nelegální. Je důležité také upozornit na jakousi pojistku či kontrolu, a to kontrasignaci udělení amnestie, jelikož tato pravomoc dle ústavy spadá do pravomocí kontrasignovaných, tzn., že je třeba spolupodpis předsedy vlády nebo jím pověřeného člena vlády. Dále v článku 63 odst. 4 Ústava ČR uvádí, že za rozhodnutí prezidenta republiky, ke kterému je třeba spolupodpis, odpovídá vláda, nikoli prezident sám. To by znamenalo, že v prípadě udělení sebeamnestie by si vláda sama u svých voličů pravděpodobně tzv. „podřizla větev“. Do pravomocí vyžadujících spolupodpis patří také pravomoc udělit amnestii. Politickou odpovědnost za amnestie nese tedy vláda. ${ }^{16}$ Ovšem právní systém může být někdy vrtkavý, a proto je třeba, aby zde byla právní úprava, která bude umožňovat kontrolu v podobě možnosti zrušení udělené amnestie nebo zákaz sebeamnestii jako takovou udělit. Jinak se budeme muset spoléhat na svůj vlastní stát, že zakročí, například žalobou k Mezinárodnímu trestnímu soudu, jelikož udělení sebeamnestie jistojistě znamená, že se daná osoba snaži něco skrývat. Na závěr Ize tedy tvrdit, že udělení sebeamnestie možné není, jelikož by to mělo dalekosáhlé právní následky a je to v rozporu s mezinárodními smlouvami a lidskými právy.

${ }^{16}$ PAVLÍČEK, V. a kolektiv. Ústavní právo a státověda, II. díl. Ústavní právo České republiky. 2., aktualizované vydání. Praha: Leges, 2015, 1152 s. 


\section{POUŽITÉ PRAMENY}

DANGL, Vojtech - BYSTRICKÝ, Valerián. Chronológia dejín Slovenska a Slovákov: Od najstarších čias po súčasnost'. Dejiny $v$ dátumoch, dátumy $v$ dejinách, II. čast. Bratislava: Veda, 2014. ISBN 978-80-224-1373-2. Kapitola 1998, s. 1024.

JAMBOR, Eduard. Vplyv Slovenskej informačnej služby na charakter a transformáciu politického systému na Slovensku do roku 1998 [online]. [cit. 2019-09-04]. Brno, 2007. Dostupné z: https://is.muni.cz/th/bvjgn/. Bakalářská práce. Masarykova univerzita, Fakulta sociálních studií. Vedoucí práce Miroslav Mareš.

LESNÁ, L'uba. Únos prezidentovho syna alebo krátke dejiny tajnej služby [s.I.]. GMT a.s., 1998. ISBN 80-967947-0-1.

Nález Ústavního soudu Slovenské republiky ze dne 31. května 2017, sp. zn. PL. ÚS 7 / 2017-159.

PAVLÍČEK, V. a kolektiv. Ústavní právo a státověda, II. díl. Ústavní právo České republiky. 2., aktualizované vydání. Praha: Leges, 2015, 1152 s.

PODIVINSKÁ, Alexandra. Ústavný zákon o zrušení Mečiarových amnestií bol neúspešný [online]. [cit. 2016-12-01]. Legal \& Economic Press, s.r.o., 2016.

PODIVINSKÁ, Alexandra. Mečiarove amnestie bránia spravodlivosti [online]. [cit. 2016-12-02]. Úřad vlády SR, 2011. PRŮŠOVÁ, Veronika. Bývalá ústavní soudkyně: Kontrolní páku u Ústavního soudu nevidím [online]. [cit. 2017-03-22]. N Press, 2017.

Rozhodnutí předsedy vlády České republiky č. 55/1998 Sb., o amnestii [online]. [cit. 2017-07-09]. Bratislava: Ministerstvo spravedInosti SR, 1998. 
Rule-of-law Tools for Post-conflict States - Amnesties. New York and Geneva: United Nations, 2009, s. 43. Dostupné z: http://www.ohchr.org/Documents/Publications/ Amnesties_en.pdf

Sdělení federálního ministerstva zahraničních věcí č. 209/1992 Sb., o sjednání Úmluvy o ochraně lidských práv a základních svobod a Protokolů na tuto Úmluvu navazujících. ŠIMÍČEK, Vojtěch - FILIP, Jan - MOLEK, Pavel - BAHÝL'OVÁ Lenka - PODHRÁZKÝ, Milan - SUCHÁNEK, Radovan VYHNÁNEK, Ladislav. Ústava České republiky. Komentář. Praha: Linde Praha, 2010. 1536 s. ISBN 978-80-7201-814-7. Ústavní zák. č. 460/1992 Sb., Ústava Slovenskej republiky. VIA IURIS. Stanovisko Amicus curiae ke konání o přezkumu usnesení Národní rady SR o zrušení tzv. Mečiarových amnestií Ústavním soudem. Dostupné z: https://viaiuris. sk/wp-content/uploads/2017/09/VIA-IURIS-list-AMICUS -CURIAE-Meciarove-amnestie-16.5.2017.pdf 